\title{
Hygienic Quality of Water Used in Some Fresh and Marine Aquacultures and Their Implications on Fish Samaa T. Hozien ${ }^{a}$, Marwa A. Hassan ${ }^{b}$, Mona M. Abdel wahab ${ }^{a}$ zamzam H. Abdel wahed ${ }^{\mathrm{b}}$ and A. M. Hassan ${ }^{\mathrm{b}}$. \\ ${ }^{a}$ Animal Health Research Institute, Ismailia, Egypt. \\ ${ }^{b}$ Departement of Animal and Poultry Hygiene, Faculty of Veterinary Medicine, Suez Canal University, Ismailia, Egypt.
}

\begin{abstract}
This study was carried out to compare between the hygienic quality of fish and water used in different aquaculture types. A total of 56 water samples and 150 fish samples also were collected from different aquacultures in Egypt. Water samples were tested for the presence of three heavy metals as Cadmium (Cd), Lead (pb) and copper (cu). Also, it were examined for their Physicochemical characteristics. Both water and fish samples were examined bacteriologically Total bacterial count(TBC), Total coliform count (TCC) and Feacal coliform count(FCC). Also, Results revealed a significant increase in $\mathrm{NH}_{3}$ of pond samples, $\mathrm{TBC}, \mathrm{FCC}, \mathrm{Cd}$, pb and $\mathrm{Cu}$ of both water and fish samples in fresh aquacultures compared to marine aquaculture. While a significant increase in $\mathrm{No}_{3}, \mathrm{Ca}^{2+}, \mathrm{Mg}^{2+}$, T.ALK , TDS, EC and $\mathrm{Cl}^{-}$in water samples of marine aquaculture in comparsion with fresh aquacultures.

This difference between two types of fish farms may attributed to natural chemistry of water used in each farm, which in turn influence the hygienic quality of the fish produced from each farm, where marine water affect the heavy metal accumulation on fish negatively either by competitive inhibiton through ions exchange in gills or by forming un absorbable precipitate. Also, the high salinity of marine water sets up a hypertonic environment which enhance bacterial death. Also, many types of bacteria are killed by the high concentration of $\mathrm{NaCl}$ in marine aquaculture.
\end{abstract}

Key words: marine aquaculture, fresh aquaculture, Heavy metals, Fish bacterial load.

\section{Introduction}

Water is the external medium for fish, so water quality is an important factor for pond management because it has a great effect on fish production. Water quality include the important components of water which should be found for the optimum fish growth, Water quality consists of physical, chemical and biological factors which control the water used for fish culture purposes. These factors are: dissolved oxygen, 
$\mathrm{pH}$, hardness, turbidity, alkalinity, nitrogenous compounds (mainly ammonia) and temperature (Ehiagbonare and Ogundiran, 2010). Untreated water and the improper way of sewage disposal system is one of the main sources for microbial water contamination which results in the accumulation of pathogenic bacteria in the commercial edible fish (Sujatha K. et al.,2011). In many countries, Increasing of the industrialization and agricultural activities lead to an increasing of discharge of chemical pollutants into the ecosystem, So increasing in metals levels in the natural waters cause a great damage of fresh and marine habitats (El Nemr, 2012). Heavy metals produce their toxic effect by producing reactive oxygen species (ROS), leading to oxidative stress. heavy metal ions are naturally toxic or carcinogenic which threat both the public health and the environment (Farombi et al. 2007). the main objectives of this study to: 1.Evaluate the physic-chemical parameters of water at some fish farms

2.Bacteriological evaluation of pond water and fish samples from different fish farms.

3.Study the possible correlation between water quality and fish.

4.Comparing the hygienic status between fresh water aquaculture and marine aquaculture.

\section{Material and Methods}

A field study was carried out during the period from November 2014 to
Apirl 2015 at three localities:- farm A (Elhosynaya -Sharkia governorate), farm B( El- Mansraa -Portsaid governorate) and farm $\mathbf{C}$ (El-Tall El-kbeer -Ismailia governorate). Wherer farm $\mathbf{A}$ and $\mathbf{C}$ are fresh aquacultures depend on agriculture drainage as source of water( Nile Tilapia and Mugil are produced) while farm $\mathbf{B}$ is a marine aquaculture( where seabass and seabream are produced). A total of 56 pond water samples and 150 fish samples also were collected at different stages of the production cycle. Water samples were collected as pre method described in (Abd El Azeem M.H.; et al,. 2012). Some parameters (Temperatures using (CRison Oxi 45p(Barchelona), $\mathrm{pH}$ using $\mathrm{pH}$ meter (Hanna HI 9147 Oxy-Check, HANNA,USA), DO using digital oxygen meter (Jenway 370pH meter $(\boldsymbol{U K})$ ) were measured during taking water samples while others were measured as quick as possible at laboratory for 1-Chemical analysis: immediate measuring of $\mathrm{EC} \mu \mathrm{S} / \mathrm{cm}$ by means of conductivity meter(Jenway 4520 condictivity $\operatorname{Meter}(\boldsymbol{U K})$, using UV screening spectrophotometric method to determine the nitrogenous compound $\left(\mathrm{NH}_{3}\right.$ according to Koroleff, $\boldsymbol{F}$. $1976, \mathrm{NO}_{2}$ according to (EPA 1979), $\mathrm{NO}_{3}$ according to (APHA,1998). T.Alkalinity determined using titrimetric method modified from method described by (APHA, 1998). Total, calcium and magnesium hardness were 
determined using Ethylene diamine tetra acetic acid (EDTA) titrimetric method according to (APHA, 1998). $\mathrm{Cl}^{-}$was determined by Argentometric Method according to (APHA, 1998).

While for heavy metal detection in water samples nitric acid $(0.001 \%$ $\mathrm{v} / \mathrm{v}$ ) was added to a portion of the filtered sample to keep the metals in suspension and the samples were kept at less than $5^{\circ} \mathrm{C}$ (Goan et al.,1992). For fish samples Tissue samples were prepared according to the method described by (Al-Ghais 1995). Lead, Cadmium, Copper were analyzed using Atomic Absorbation Spectrophotometer (thermo electron corporation $S$. series, AA spectrometer type S4 A A system, S.No.GE 711838).

For Bacteriological examination: all water and fish intestinal samples were estimated using drop plate technique described by (Herigstad et al. 2001) onto the following media: Standard plate count agar ( Difco, USA ) for total bacterial count (TBC) ;EMB agar (Lab M, LAB061, UK) for E. coli, and total Enterobacteriacae; Total aerobic bacteria, E. coli and total Enterobacteriacae were cultivated at $37^{\circ} \mathrm{C}$ for $24-48 \mathrm{~h}$. Fecal coli form cultivated at $40^{\circ} \mathrm{C}$ for $48-72 \mathrm{hr}$.

\section{Statistical Analysis:}

Results are expressed as means \pm SEM. Results were tested for differences by performing the ANOVA using MINITAB 17 computer, Correlation Coefficient were performed using IBM SPSS software computer program version 16, NY, USA (Inc.,1989-2010). Differences were considered statistically significant at $\mathrm{p}<0.05$.

\section{Results:}

Table (1): Physico-chemical parameters of water (water-ponds) used in different fish farms at different localities:

\begin{tabular}{|c|c|c|c|}
\hline \multirow{2}{*}{ paramter } & Farm A & Farm B & Farm C \\
\cline { 2 - 4 } & Mean \pm SE & Mean \pm SE & Mean \pm SE \\
\hline $\mathbf{D O}(\mathbf{m g} / \mathbf{l})$ & $5.02 \pm 0.31^{\mathbf{c}}$ & $6.47 \pm 0.07^{\mathbf{a}}$ & $5.74 \pm 0.05^{\mathbf{b}}$ \\
\hline $\mathbf{p H}$ & $8.4 \pm 0.06^{\mathbf{a}}$ & $8.5 \pm 0.05^{\mathbf{a}}$ & $8.6 \pm 0.12^{\mathbf{a}}$ \\
\hline $\mathbf{T e m p}$ & $19.6 \pm 0.58^{\mathbf{b}}$ & $23.8 \pm 0.83^{\mathbf{a}}$ & $21.6 \pm 0.79^{\mathbf{b}}$ \\
\hline $\mathbf{T D S}$ & $2896 \pm 140^{\mathbf{b}}$ & $19553 \pm 752^{\mathbf{a}}$ & $450 \pm 23.2^{\mathbf{c}}$ \\
\hline $\mathrm{NH}_{3}(\mathrm{mg} / \mathrm{l})$ & $0.33 \pm 0.23^{\mathbf{a b}}$ & $0.04 \pm 0.01^{\mathbf{b}}$ & $1.33 \pm 0.74^{\mathbf{a}}$ \\
\hline $\mathrm{NO}_{2}(\mathrm{mg} / \mathrm{l})$ & $0.18 \pm 0.07^{\mathbf{a}}$ & $0.18 \pm 0.07^{\mathbf{a}}$ & $0.03 \pm 0.009^{\mathbf{b}}$ \\
\hline $\mathrm{NO}_{3}(\mathrm{mg} / \mathrm{l})$ & $0.12 \pm 0.06^{\mathbf{b}}$ & $0.53 \pm 0.09^{\mathbf{a}}$ & $0.32 \pm 0.06^{\mathbf{a b}}$ \\
\hline $\mathbf{T . h a r d n e s s}^{\mathbf{b}}$ & $958 \pm 118^{\mathbf{b}}$ & $6750 \pm 1260^{\mathbf{a}}$ & $\underline{140 \pm 8^{\mathbf{b}}}$ \\
\hline $\left.\mathbf{C a}^{\mathbf{}} \mathbf{2} \mathbf{m g} / \mathbf{L}\right)$ & $108 \pm 15^{\mathbf{b}}$ & $561 \pm 144^{\mathbf{a}}$ & $\underline{12.58 \pm 5.75^{\mathbf{b}}}$ \\
\hline $\mathbf{M g}^{+2}(\mathrm{mg} / \mathrm{L})$ & $206 \pm 30^{\mathbf{b}}$ & $1284 \pm 250^{\mathbf{a}}$ & $\underline{29.3 \pm 2.3^{\mathbf{b}}}$ \\
\hline $\mathbf{C l}^{\mathbf{b}}(\mathbf{m g} / \mathbf{l})$ & $1384 \pm 83^{\mathbf{b}}$ & $10547 \pm 741^{\mathbf{a}}$ & $197 \pm 37.9^{\mathbf{b}}$ \\
\hline $\begin{array}{c}\mathbf{T} . \mathbf{A l k a l i n t y} \\
(\mathbf{m g C a C o} / \mathbf{L})\end{array}$ & $132.8 \pm 29.7^{\mathbf{b}}$ & $413.3 \pm 41^{\mathbf{a}}$ & $\underline{29 \pm 2.54^{\mathbf{c}}}$ \\
\hline
\end{tabular}


*Means with different superscripts at the same row are statistically different at $\mathrm{P}<0.05$

**A=Sharkia farm , B=Portsaid farm, $\mathrm{C}=\mathrm{El}$ Tall-El kabeer farm.

*** Highlighted numbers are the highest significance values while underlined numbers are the lowest significance value.

Table (2): Bacteriological evaluation of pond water and fish samples in different fish farms at different localities:-

\begin{tabular}{|c|c|c|c|}
\hline \multirow{2}{*}{ paramter } & Farm A & Farm B & Farm C \\
\cline { 2 - 4 } & Mean \pm SE & Mean \pm SE & Mean \pm SE \\
\hline \multirow{2}{*}{$\begin{array}{c}\text { Ponds: } \\
\text { T.B.C } \\
\text { T.E.C } \\
\text { T.C.C } \\
\text { F.C.C }\end{array}$} & $5.13 \pm 0.15^{\mathbf{a}}$ & $\underline{4.70 \pm 0.14^{\mathbf{b}}}$ & $4.93 \pm 0.36^{\mathbf{a b}}$ \\
\cline { 2 - 4 } & $3.83 \pm 0.35^{\mathbf{a}}$ & $4.34 \pm 0.23^{\mathbf{a}}$ & $3.87 \pm 0.7^{\mathbf{a}}$ \\
\cline { 2 - 4 } & $2.12 \pm 0.57^{\mathbf{a}}$ & $1.56 \pm 0.59^{\mathbf{b}}$ & $3.12 \pm 0.79^{\mathbf{a}}$ \\
\hline Fish Ms: & $1.26 \pm 0.54^{\mathbf{a}}$ & $0.59 \pm 0.40^{\mathbf{b}}$ & $0.59 \pm 0.40^{\mathbf{b}}$ \\
\hline T.B.C & $6.410 \pm 0.118^{\mathbf{a}}$ & $\underline{6.030 \pm 0.114^{\mathbf{b}}}$ & $6.412 \pm 0.22^{\mathbf{a b}}$ \\
\hline T.E.C & $4.916 \pm 0.243^{\mathbf{a}}$ & $3.704 \pm 0.271^{\mathbf{b}}$ & $4.969 \pm 0.388^{\mathbf{a}}$ \\
\hline T.C.C & $3.032 \pm 0.364^{\mathbf{a}}$ & $2.104 \pm 0.294^{\mathbf{b}}$ & $4.259 \pm 0.367^{\mathbf{a}}$ \\
\hline F.C.C & $3.873 \pm 0.291^{\mathbf{a}}$ & $0.909 \pm 0.235^{\mathbf{b}}$ & $3.481 \pm 0.324^{\mathbf{a}}$ \\
\hline
\end{tabular}

*Means with different superscripts at the same row are statistically different at $\mathrm{P}<0.05$

**A=Sharkia farm, $\mathrm{B}=$ Portsaid farm, $\mathrm{C}=\mathrm{El}$ Tall-El kabeer farm.

T.B.C $=$ Total Bacterial Count, T.E.C $=$ Total Enterobacterace Count, T.C.C=Total Coliform count, F.C.C=Feacal Coliform Count.

*** Highlighted numbers are the highest significance values while underlined numbers are the lowest significance value.

Table (3): Heavy metal Concentration $(\mathrm{Cd}, \mathrm{Pb}, \mathrm{Cu})$ of pond water and fish samples in different fish farms at different governorates:-

\begin{tabular}{|c|c|c|c|}
\hline & Farm A & Farm B & Farm C \\
\hline \multirow{3}{*}{$\begin{array}{l}\text { Pond: } \\
\mathrm{Cd}(\mathrm{mg} / \mathrm{l}) \\
\mathrm{Pb}(\mathrm{mg} / \mathrm{l}) \\
\mathrm{Cu}(\mathrm{mg} / \mathrm{l})\end{array}$} & $0.07 \pm 0.07^{\mathrm{a}}$ & $0.00^{\mathrm{a}}$ & $0.003 \pm 0.003^{b}$ \\
\hline & $1.10 \pm 1.07^{\mathrm{a}}$ & $0.01 \pm 0.01^{\mathbf{b}}$ & $1.51 \pm 0.68^{\mathrm{a}}$ \\
\hline & $0.30 \pm 0.16^{\mathrm{a}}$ & $\underline{0.07 \pm 0.01^{\mathbf{b}}}$ & $0.43 \pm 0.12^{\mathrm{a}}$ \\
\hline \multirow{3}{*}{$\begin{array}{l}\text { Fish Ms: } \\
\mathrm{Cd}(\mathrm{mg} / \mathrm{g}) \\
\mathrm{Pb}(\mathrm{mg} / \mathrm{g}) \\
\mathrm{Cu}(\mathrm{mg} / \mathrm{g})\end{array}$} & $0.006 \pm 0.002^{a}$ & $\underline{0.001 \pm 0.0007^{b}}$ & $0.003 \pm 0.0002^{\mathrm{ab}}$ \\
\hline & $0.12 \pm 0.09^{\mathrm{a}}$ & $0.04 \pm 0.031^{\mathbf{b}}$ & $0.03 \pm 0.01^{\mathrm{b}}$ \\
\hline & $0.033 \pm 0.003^{\mathrm{a}}$ & $0.034 \pm 0.004^{\mathrm{a}}$ & $0.07 \pm 0.039^{\mathrm{a}}$ \\
\hline
\end{tabular}

*Means with different superscripts at the same row are statistically different at $\mathrm{P}<0.05$

$* * \mathrm{~A}=$ Sharkia farm, $\mathrm{B}=$ Portsaid farm, $\mathrm{C}=$ Telkbeer farm.

*** Highlighted numbers are the highest significance values while underlined numbers are the lowest significance value. 
Table (4): Correlation between different physic-chemical parameters of pond water and heavy metals concentrations in pond water samples and fish muscles:-

\begin{tabular}{|c|c|c|c|c|c|c|c|c|c|c|c|}
\hline & pH & TDS & chloride & Mgcone & TCa & Cadmium & lead & copper & $\begin{array}{l}\text { Fish } \\
\text { CD }\end{array}$ & fishPb & FishCU \\
\hline pH & 1 & 0.009 & 0.063 & 0.053 & 0.015 & 0.035 & $-.595-$ & $-.710^{*}$ & $-.452^{*}$ & $-.072-$ & $-.120-$ \\
\hline TDS & & 1 & $.769^{* *}$ & $.755^{* *}$ & $.560^{* *}$ & -.369 & -.479- & -.589- & $-.498^{*}$ & 0.003 & 0.094 \\
\hline chloride & & & 1 & $.348^{* *}$ & 0.081 & $-.346-$ & -.461- & $-.580-$ & $-.460^{*}$ & 0.155 & 0.17 \\
\hline Mgconc & & & & 1 & $.892^{* *}$ & $-.362-$ & -.414- & -.498- & $-.430-$ & 0.018 & 0.115 \\
\hline TCa & & & & & 1 & $-.251-$ & $-.361-$ & -.446- & $-300-$ & 0.244 & 0.193 \\
\hline Cadmium & & & & & & 1 & - $-249-$ & -.177- & 0.252 & $-.357-$ & -.438- \\
\hline lead & & & & & & & 1 & $.971^{* *}$ & 0.052 & -.177- & -.443- \\
\hline copper & & & & & & & & 1 & 0.176 & $-.303-$ & -.494- \\
\hline FishCD & & & & & & & & & 1 & 0.407 & 0.374 \\
\hline FishPb & & & & & & & & & & 1 & $.734^{* *}$ \\
\hline FishCU & & & & & & & & & & & 1 \\
\hline
\end{tabular}

Correlation is significant at the 0.05 level (2-tail)*

** Correlation is significant at the 0.01 level (2-tailed). 
Table (5): Correlation between different physic-chemical parameters of pond water and bacteriological findings in water and fish intestinal samples:

\begin{tabular}{|c|c|c|c|c|c|c|c|c|c|c|c|c|c|}
\hline & pH & DO & Temp. & TDS & Amonia & Nitrite & Nitrate & WFC & WTC & WTBC & FFC & FTC & FTBC \\
\hline pH & 1 & $.220-$ & 0.132 & 0.009 & -.027- & $-.374^{4 *}$ & -207 & 0.171 & 0.255 & 0.032 & - & -.063- & 0.075 \\
\hline DO & & 1 & $-.843^{* * *}$ & $.324^{*}$ & 0.143 & 0.14 & $.486 "$ & 0.13 & 0.078 & 0.104 & - & -.074- & $-.281^{*}$ \\
\hline Temp. & & & 1 & -174- & -101- & - & $-296^{*}$ & $.166-$ & $-.048-$ & - & - & -.074- & $.287^{*}$ \\
\hline TDS & & & & 1 & $-.266^{*}$ & 0.075 & $.429^{* * *}$ & $.121-$ & $-319 *$ & - & $.376^{* *}$ & $.468 * *$ & -0.087 \\
\hline$\underset{\text { ia }}{\text { Ammon }}$ & & & & & 1 & 0.127 & 0.196 & 0.024 & $.353 * *$ & $.389^{* * *}$ & 0.06 & $-.088-$ & - \\
\hline Nitrite & & & & & & 1 & 0.26 & 0.136 & 0.153 & 0.154 & 0.157 & 0.236 & 0.135 \\
\hline Nitrate & & & & & & & 1 & . & 0.067 & 0.206 & $-.276^{*}$ & $-.313^{*}$ & $.367^{* *}$ \\
\hline WFC & & & & & & & & 1 & $.542^{* * *}$ & $.496=$ & 0.225 & 0.213 & 0.126 \\
\hline WTC & & & & & & & & & 1 & $.641^{* *}$ & 0.137 & $.286 *$ & -085- \\
\hline WTBC & & & & & & & & & & 1 & 0.09 & 0.119 & -.124- \\
\hline FFC & & & & & & & & & & & 1 & $.354 * *$ & $.448^{* *}$ \\
\hline FTC & & & & & & & & & & & & 1 & $.410^{* *}$ \\
\hline FTBC & & & & & & & & & & & & & 1 \\
\hline
\end{tabular}

**. Correlation is significant at the 0.01 level (2-tailed).

*.Correlation is significant at the 0.05 level (2-tailed).

\section{Discussion:}

In accordance with results of TDS of the examined pond water samples showed in Table (1) it was high in Port said farm( B) in comparison with Sharkia farm (A) and ismailia farm (C), this agreed with a strong negative correlation showed in Table (4) between the salinity (TDS) and chloride with the heavy metal concentration in water and fish muscles, where results in Table (3) indicated that the detected heavy metals concentrations was the lowest at farm B in comparsion with other fresh aquacultures in both water and fish samples.

Concerning ammonia concentration in pond water, it detected to be the highest at farm (C) and the lowest in farm (B), this variation in ammonia mean values may attributed to areas variations and the rate of water exchange in each farm, where farms $\mathrm{A}$ and $\mathrm{C}$ is highly close to agriculture area that might be a 
source of pollution to water. Also, the rate of water exchange was the lowest in farm $\mathrm{C}$ as it was $20 \%$ weekly or each 2 weeks, in comparison with the high regular water exchange rate in other farms. Plus the high stocking density in farm $\mathrm{C}$ increase ammonia concentration in water.

Also results in Table (2) revealed that the means of bacteriological findings TBC, TCC, FCC was detected to be the lowest in farm (B) (marine aquaculture) in comparison with farms (A) and (C) especially in fish intestinal samples this could be related to many factors: Firstly, that the high salinity of farm B water sets up a hypertonic environment. Thus the water (solvent) in the bacteria would diffuse out of the bacterium by a process called "osmosis", Because of the loss of water, the bacteria will shrivel up and eventually die. Also , many types of bacteria are killed by the high concentration of $\mathrm{NaCl}$ in marine aquaculture. Secondly, the component of fish endogenous microbiota depends mainly on genetic, nutritional and environmental factors, where it is supposed that Gram-negative facultative anaerobic bacteria like Acinetobacter, Aeromonas, Flavobacterium/ Cytophaga, Micrococcus, , Pseudomonas and Vibrio constitute the main endogenous microbiota of a lot of marine fish species Cahill (1990); Onarheim et al. (1994) and Blanch et al. (1997). The opposite was found in freshwater fish species, where the endogenous microbiota of freshwater fish was predominated by members of the genera Aeromonas, Acinetobacter, Pseudomonas, Flavobacterium, some representatives of the Enterobacteriaceae family, Clostridium and Fusobacterium Sakata (1990); Huber et al. (2004) and Kim et al. (2007).

The obtained bacteriological findings in water and fish samples are nearly the same due to close correlation between the bacteria present in water and in organs of fishes with E. coli dominating followed by P. aeruginosa in some tissues of cultured carps as Labeo rohita, Cirrhinus mrigala and Cyprinus carpio polycultured, in a freshwater pond.

Correlation between measured parameters indicated that in Table (4) a strong negative correlation showed in between the salinity (TDS) and chloride with the heavy metal concentration in water and fish muscles, this could be attributed to the fact that high salinity, high $\mathrm{Cl}$-, other component of sea- water, inhibit the absorption of this pollutant through fish gills either by competitive inhibition or by combine with this pollutant lead to un absorbable precipitate. Where Barbara and Malgorzata (2006) stated that accumulation of metal in fish Muscles depends on the heavy metal concentration, time of exposure, the manner of metal uptakes and other environmental 
factors as; water temp, $\mathrm{pH}$, hardness and salinity, also some intrinsic factors as fish age and feeding habits play an important role. It was detected that high water hardness reduces lead toxicity in fish by formation of a significant inorganic complex that reduce lead availability to fish. Hodson et al. ( 1984). Also in Table (4) there is a strong negative correlation between DO and water temperature. This agreed with Diaz and Rosemberg (1995) and $W u$ (1999) was found that in tropical aquatic environments, high temperatures lead to sever decomposition of the organic matters which cause a drastic decrease in the levels of water dissolved oxygen (DO), which called environmental hypoxia. Aquatic hypoxia may also exist from the anthropogenic inputs of nutrients and organic matter in lakes and ponds.

Table (4) revealed a negative correlation between $\mathrm{pH}$ and cadmium $(\mathrm{r}=-0.452)$, lead $(\mathrm{r}=$ 0.072) and copper $(r=-0.120)$ in fish muscles which agreed with Raja et al. (2009) explained that acidic water affects heavy metal bioaccumulation in fish muscles, either indirectly by changing the heavy metal solubility or directly by damaging the gills epithelia, so become more permeable to metals. Part et al. (1985) stated that The acidic conditions of aquatic environment might increase the free divalent ions of many heavy metals that absorbed by fish gills.
Results in Table (5) showed a positive correlation between ammonia concentration and TBC and TC $(r=0.389,0.353$ at $p>0.01$ respectively) in water samples where impairment water quality in fish ponds like high ammonia (either raised due to high nutrition or agriculture drainage which rich with organic matter that observed in freshwater farms), increase the risk of bacterial growth as supported by Markosova and Jezak (1994) and Jana and De (1990). And negative correlation between water $\mathrm{pH}$ and ammonia concentration $(\mathrm{r}=-0.27)$ which agreed with Chew et al. (2003) who reported that by lowering of environmental $\mathrm{pH}$ we can deal with the high environmental ammonia levels through reducing the concentration of NH3 in the water, consequently reduce its level in the fish, constituting "environmental ammonia detoxification.

\section{Conclusion:}

In conclusion our results indicated that there was a strong negative correlation between the TDS, CL in water and persistence of heavy metals in water and fish muscles. Also, a strong positive correlation between ammonia concentration and TBC, FC in water samples and a negative correlation between water $\mathrm{pH}$ and cadmium, lead and copper in fish muscles. From the hygienic point of view, marine aquaculture supply the market with a safe fish for food in comparsion 
with fresh water aquacultures that mostly suffers from high ammonia concentrations, high bacteriological load, high feacal coliform content, high heavy metals residues. So exploitation our large sectors of marine water ( Meditterean sea, Redwater sea, other marine lakes and canals) would be the Perfect replacement for most of fresh water aquaculture that provide bad quality product.

\section{References:}

-Al-Ghais, S.M.(1995):Heavy metal concentrations in the tissue of sparus sarba forskal,1775 from the United Arab Emirates. Bulletin of Enviromental Contamination and Toxicology, 55:581-587.

- APHA (American public Health Association)(1998): standard methods for the examination of water and wastewater, 20th ed.,L . Clesceri, S.;Greenberg ,A.E.; and Eaton, A.D. editors.

- Barbara, J. and Malgorzata,W. (2006):the metal uptake and accumulation in fish living in polluted waters. Soil and water pollution Monitoring Protection and Remediation, 69:107-114.

-Blanch A.R., Alsina M., Sim'onM\& Jofre J (1997): Determination of bacteria associated with reared turbot (Scophthalmus maximus) larvae. J Appl Microbiol 82: 729-734.

-Chew, S.F., Hong, L.N., Wilson, J.M., Randall, D.J.,\& Ip, Y.K., (2003): Alkaline environmental $\mathrm{pH}$ has no effect on the excretion of ammonia in the mudskipper Periophthalmodo schlosseri but inhibits ammonia excretion in the related specie Boleophthalmus boddaerti. Physiol. Biochem. Zool. 76: 204-214.

Diaz, J.R. \& Rosemberg, R., (1995): Marine benthic hypoxia: a review its ecological effects and the behavioral responses of benthic macrofauna. Oceanogr. Mar. Biol. An. Rev. 33: 245-303.

. Ehiagbonare J. E.\& Ogundiran Y. O. (2010): Physico-chemical analysis of fish pond waters in Okada and its environs, Nigeria. Afr. J. Biotechnol. 9(36): 59225928.

El Nemr, A., El-Sikaily, A., Khaled, \& A., Ragab, S., (2012): Distribution patterns and risk assessment of hydrocarbons in bivalves from Egyptian Mediterranean coast. Blue Biotechnology Journal, 1 (3): 457472.

EPA (Environmental Protection Agency)(1979): Methods for Chemical Analysis of Water and Wastes. Method 353.3. U.S. Environmental Protection Agency, Washington, D.C.

Farombi, E. O., Adelowo, O. A.\&Ajimoko, Y. R., (2007): Biomarkers of oxidative stress and heavy metal levels as indicators of environmental pollution in African Cat fish (Clarias gariepinus) from Nigerian Ogun River. Int J Environ Res Public Health. 2007 Jun;4(2):158-65. 
Cahill MM (1990) Bacterial flora of fishes: a review. Microb Ecol19: 21-41.

Goan,H.C.;

Burcham

,P.H.;Denton,\& Draughton,F.A. (1992): Quality of water on tennessee poultry farms.poult.sci.71-103(abstr.).

Hodson P.V., Whittle D.M., Wong P0T.S, Borgmann U, Thomas R.L., Chau Y.K., Nriagu J.O. \& Hallet DJ (1984). Lead contamination of the Great Lakes and its potential effects on aquatic biota. In Toxic contaminants in the Great Lakes. Nriagu JO and Simmons MS (Eds.), John Wiley and Sons, Indianapolis.

Herigstad, B.; Hamilton, M. \& Heersink, J. (2001): How to optimize the drop plate method for enumerating bacteria. J Microbiol Meth, 44(2): 121-129.

Huber I, Spanggaard B., Appel KF, Rossen L., Nielsen T. \& Gram L.(2004): Phylogenetic analysis and in situ identification of the intestinal microbial community of rainbow trout (Oncorhynchus mykiss, Walbaum). J Appl Microbiol 96: 117-132.

Jana, B.B. \& De, U.K.(1990): Spatial and Seasonal distribution of heterotrophic bacteria in pond water and sediments under different management species. International Revue der Gesamten Hydobiologie, 75:639-648.

Kim D.H., Brunt J. \&Austin B. (2007): Microbial diversity of intestinal contents and mucus in rainbow trout (Oncorhynchus mykiss). J Appl Microbiol 102: 1654-1664.

Koroleff, F.(1976): Determination of ammonia.In Methods of Seawater Analysis (K. Grasshofi,ed.).Verlag Chemie, pp.126-133.

Markosova, R. and Jezk, J. (1994): Indicator bacteria and limnological parameters in fish ponds. Water Res., 28:2477-2485.

Abd El Azeem M.H.; Hassan, A. M.; Hussein, M. M.; Zamzam, H. Abd El wahed and Saleh, $R$. E.(2012): Some heavy metal pollutants in fish farms and Effect of garlic on their bioaccumulation in Oreochromas niloticus. SCVMJ, XVII (1):57-69.

Onarheim AM, Wiik R., Burghardt J. and Stackebrandt E. (1994): Characterization and identification of two Vibrio species indigenous to the intestine of fish in cold sea water; description of Vibrio iliopiscarius sp. nov. Syst Appl Microbiol17: 370-379.

Part P., Svanberg O. \& Kiessling A. ( 1985); The Availability of Cadmium to Perfused Rainbow Troutgills in Different Water Qualities, Water Research, Vol. 19 (2):427-434.

Raja ,P.;Veerasingam, S.,:Suresh,g.;Marichamy, G. \&Venkatachalapathy, R.(2009): heavy metal concentration in four commercially valuable marine edible fish species from Parangipettai coast,Southeast coast of India.Indian International Journal 
of Animal Veterinary

Advances, 1:10-14.

Sakata T (1990): Microflora in the digestive tract of fish and shellfish. Microbiology in Poecilotherms (Lesel R, ed), pp. 171-176. Elsevier, Amsterdam.

Sujatha K., Senthilkumaar P., Sangeetha S. \& Gopalakrishnan. (2011):Isolation of human pathogenic bacteria in two edible fishes, Priacanthus hamrur and Megalapis cordyla at Royapuram waters of Chennai, India. Indian Journal of Science and Technology. 4(5):539-541.

Wu, R.S.S., (1999): Eutrophication, water borne pathogens and xenobiotic compounds: environmental risks. Mar. Pollut. Bull. 39, 11-22.

\section{الملخص العربى}

لقد أجريت دراسة ميدانية لتقبيم الجودة الصحية للمياه المستخدمة في المزارع السمكية مع تقدير

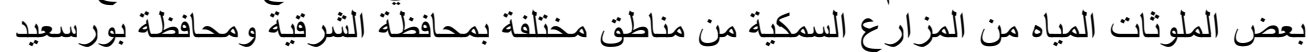

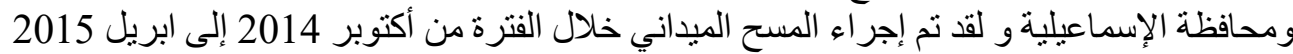

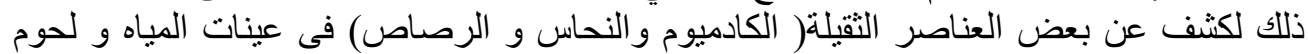

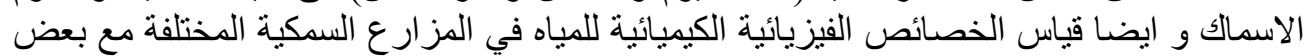

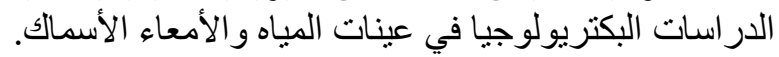

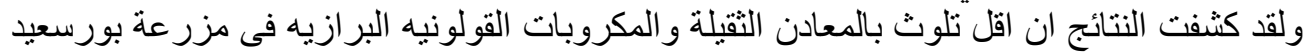

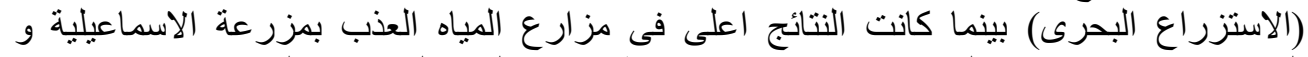
الثرقيه. و ايضا كثفت الدراسة عن علاقات ارتباط بين مختلف العناصر الثياه بالمباه و تاثير بعضهما 